\title{
THE EVALUATION OF TRADE CREDIT INSURANCE IN LITHUANIAN BUSINESS MARKET AS A CREDIT RISK MANAGEMENT TOOL
}

\author{
Aleksandra Lezgovko', Andrej Jakovlev \\ ${ }^{1}$ Mykolas Romeris University, Insurance and risk management institute, Lithuania, aleksandra@draudimas.com \\ ${ }^{2}$ Mykolas Romeris University, Lithuania, andrej.jakovlev.lt@gmail.com
}

\begin{abstract}
In today's trade, the vast majority of commercial transactions in both domestic and international trade are concluded by applying trade credit terms. The aim of this article is to analyse the trade credit insurance and, according to the methodology, to evaluate it as a credit risk management tool in the context of Lithuanian business market. The authors have proposed a methodology that combines theoretical and practical research methods. First of all, with assistance of qualitative analysis, the alternative external credit risk management tools were examined. Such analysis allows not only to identify the advantages, disadvantages and benefits of researched risk management tools but also to assess the efficiency and rationality of trade credit insurance in the context of alternative methods. In order to carry out an assessment in the practical aspect, considering the lack of statistical data, it was decided additionally to perform an expert evaluation. After performing an assessment of trade credit insurance, it was concluded that in international trade, with a large buyer portfolio and high sales volume, the trade credit insurance becomes the most effective and rational way to manage credit risk, which eliminates the losses because of the debtor's insolvency or bankruptcy, manages countries and sector's risks and helps to discipline the debtor, what determines the decline in overdue accounts frequencies, amounts and volumes.
\end{abstract}

Keywords: insurance, trade credit insurance system, insurance market

JEL Classification: G22, G23

\section{Introduction}

The topic of this article is relevant because in modern trade, the vast majority of commercial transactions in both domestic and international trade are formed, namely, by applying trade credit conditions, thus the creditor risks that in case if the debtor is unable to fulfil its debt obligations, the company will not receive its sales revenue. As market conditions are changing and the competition is getting more intensive, in order to grow and develop Lithuanian business, representatives are forced to search for new export markets, so the corporate trade credit risk environment expands. Also, it is extremely important for business representatives to know what are the effective and rational methods of trade credit risk management and what is the efficiency of such management methods. However, during the analysis of Lithuanian and foreign scientific literature, it was noticed that trade credit risk management is paid relatively little attention - the trade credit risk management is usually studied only in the context of company's financial analysis, offering methods that are based on internal management resources. During the analysis of the scientific literature, it was noticed that there is no unified description of the trade credit concept available. Paul and Boden (2012) provide a description of the concept of credit based on the origin Latin word credere (faith, trust) or creditum (loan debt). Ferrando and Mulier (2012) indicate that trade credit as a delay between the delivery of goods and services and the payment for them. However, Rutkauskas et al. (2008) argues that in most cases, credit is still described as an economic-monetary relationship. According to Jasiene and Laurinavicius (2009), usually, there are commodity and monetary forms of credit distinguished. Pike and Cheng (2001) describe trade credit as a process comprising the combined commodity-financial transaction. The authors believe that the exchange of goods (or services) is separated from the exchange of money in terms of time. Nilsen (2002) compares credit with a loan and, therefore, describes the trade credit as 
supplier's short-term loan to the purchaser. But Paul (2007) stated that the supplier's (non-financial organizations) goal accepting trade credit terms is, namely, to sell its goods and not to provide financial resources to the debtor. Pridotkiene and Snieskiene (2011) describe trade credit as a process when a company sells goods or provides services, allowing the buyer to pay after a pre-agreed period. By providing deferred payment terms, the company expects to achieve some certain materialistic and (or) non-materialistic benefits - such as increased competitiveness, customer portfolio growth, future increase in sales revenue and the like. Ferrando and Mulier (2012) describe the use of trade credit of a firm like a twofold process in which a firm can receive trade credit from its supplier (accounts payable) and, in turn, can extend trade credit to its customers (accounts receivables). Trade credit is offered by suppliers to their customers as an alternative to pre-payment or cash on delivery terms, or the need for expensive bank letters of credit, providing time for the customer to generate income from sales before paying for the product or service (Jones, 2010).

Trade credit (or sometimes called commercial credit) is seen as the most popular form of payment and in the scientific literature is considered as one of the most important precondition for company's business and competitiveness development (Pridotkiene, Snieskiene, 2011). Whilst early trade credit theories relate the use of trade credit to the presence of information asymmetries and the monitoring advantage that suppliers have over banks, more recent analyses focus on the importance of trade credit (mainly in the form of accounts receivable) as a cash management tool (Ferrando, Mulier, 2012).

Particularly, very little attention is paid in order to determine the effectiveness and disadvantages of external trade credit risk management methods. Therefore, it was decided to research the trade credit insurance and the following aim of the research was raised - to evaluate it as a credit risk management tool in the context of Lithuanian business market. The carried-out assessment was based on a major problem of the research - is the trade credit insurance is an effective and rational way to manage credit risk in Lithuanian business market? Also, the objectives of the research were nominated: to analyse the concept of the trade credit risk, to research and present the trade credit insurance assessment methodology, to investigate the trade credit insurance, herewith the advantages and disadvantages of alternative credit risk management instruments, and to make an assessment of its efficiency and rationality as a credit risk management tool in the context of Lithuanian business market. Research methods used in this study are analysis of scientific literature; analysis of statistical data; qualitative comparative analysis; and expert evaluation, calculation and assessment of Kendall's concordance coefficient; empirical research is carried out.

During the empirical research, the following hypothesis of this article was nominated: the trade credit insurance is an effective and rational way to manage credit risk in order to develop the business in Lithuanian business market. Our empirical research has confirmed this hypothesis, that is, both the data obtained during the expert evaluation and the data obtained from qualitative comparative analysis confirmed that trade credit insurance is the most effective and rational credit risk management tool in cases when trading goods or providing services in domestic and especially in foreign markets and in cases of large buyer portfolio. It eliminates losses occurred because of the debtor's insolvency or bankruptcy risks and manages countries and economical sector risks, whilst providing the opportunity to use additional factoring service to finance the commercial transactions and to control the working capital flow and to obtain more favourable conditions for trade financing from commercial banks. Also, during the research, it was determined that the implementation of insurance in the management of company's buyer portfolio credit risk allows the policyholder to achieve a higher reliability and credit rating and also is an efficient method for optimising company's administrative costs. All of this allows the businesses representatives to focus more on the core business, increase its operational efficiency and gain a competitive advantage, which enables the development of the business. At the end of the article, the conclusions and recommendations on how to properly choose an effective credit risk management tool and when trade credit insurance can be used as an efficient and rational method to manage credit risks is provided. 


\section{The conception of the trade credit insurance as a credit risk management tool}

The sales of goods and services are exposed to a significant number of risks, many of which are not within the control of the supplier. According to Jones (2010) and Li, Zhen and Cai (2014), the highest of these risks and one that can have a catastrophic impact on the viability of a supplier is the failure of a buyer to pay for the goods or services he or she has purchased.

Losses attributed to non-payment or bankruptcy occurs regularly. Default rates vary by industry sector and country from year to year, and no industry or company is safe from trade credit risk. In order to avoid non-payment risk and to ensure ready access to bank financing, suppliers can purchase trade credit insurance, which is an insurance policy and risk management product that covers payment risk resulting from the delivery of unpaid goods or services. Li, Zhen and Cai (2014) describe trade credit insurance as one of the most important risk management tools that is widely used in company's daily operation.

Approximately $90 \%$ of the world's trade credit insurance market is covered by 'Big Three' insurers Euler Hermes, Coface and Atradius. Therefore, the authors will use the information provided by the 'Big Three' and the largest worldwide broker AON in order to research the main operational principles of trade credit insurance as a trade credit risk management tool.

Trade credit insurance policies are very flexible and consist of three main types of cover:

- Portfolio cover - it is the most common type of trade credit insurance that typically covers firm's whole sales turnover and all of the buyers, above a pre-agreed first loss level. The underwritten buyer portfolio is constantly monitored and any changes in the status of a buyer are provided to the seller, so the firm could make appropriate decisions to avoid or mitigate the non-payment risk;

- Single risk or buyer cover - this type of cover is particularly useful for organisations that deal with only one buyer or have significant concentration of exposure to one buyer.

- Selected risks cover - can cover against certain selected risks. Two of the most common reasons for choosing this type of cover are the wish to cover key concentration exposures or receivables that will be assigned to a bank.

According to Euler Hermes, Coface, Atradius and The International Credit Insurance \& Surety Association (ICISA), the major part of trade credit insurance policies issued are the portfolio cover type, also referred to as whole turnover cover. This type of insurance policy covers all the buyers in exchange for a premium, which is based on the annual turnover and credit risk level of its buyers. The policyholder receives protection up to an agreed percentage of any losses incurred against late payment or the failure to pay by its buyers. The basic operation scheme of the trade credit insurance and the role of the trade credit insurer in the transactions between seller and buyer can be found in Figure 1.

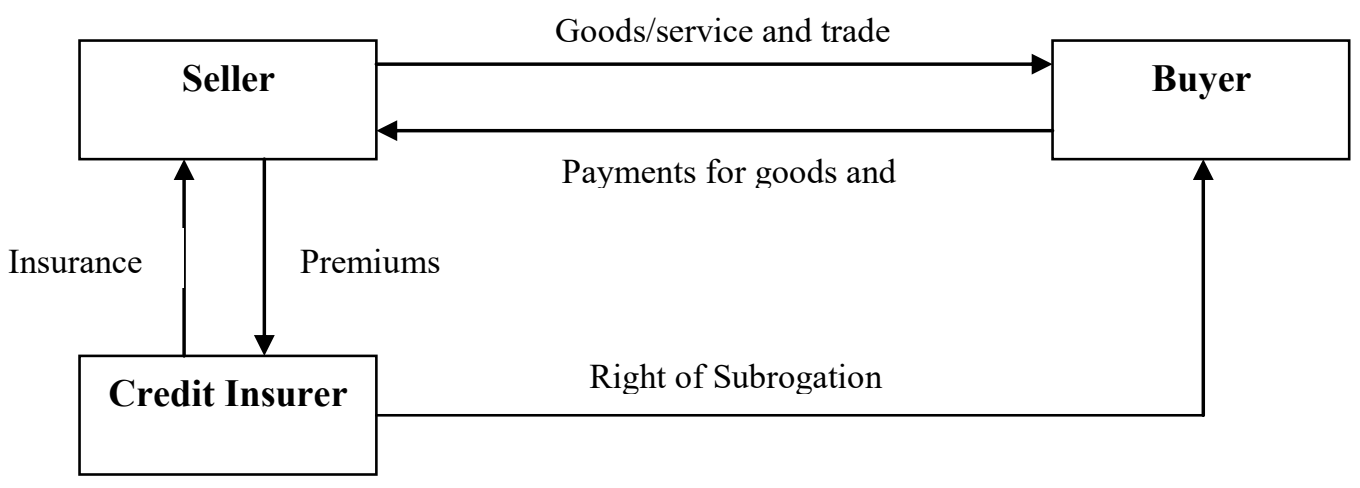

Figure 1. The role of the trade credit insurer in the transactions between seller and buyer (Sources: Jones, 2010, p. 6) 
According to Euler Hermes, Coface, Atradius and AON information sources and Van der Veer (2011, 2015), trade credit insurance protects the seller from the risk of buyer non-payment, which can occur due to commercial and political risk (in case of international trade). Trade credit risk insurance can be defined as a risk management product offered by private insurance companies and governmental export credit agencies to business entities that need to protect their accounts receivable from loss because of credit risks, such as protracted default, insolvency or bankruptcy of the buyer. Trade credit insurance policies are very flexible and consist of portfolio, single risk / buyer and selected risk covers. Trade credit insurance protects the seller from the risk of buyer non-payment, which can occur due to commercial and political risk. Consequently, trade credit insurers mostly cover short-term commercial and political risks for periods between 30 and 180 days, establish credit limits and terms of business for each particular buyers and have the right to reduce or cancel credit limits of a specific buyer if it's financial situation deteriorates. Moreover, trade credit insurance policies never cover $100 \%$ of the risks assumed and insured percentage do not exceed $85-90 \%$ of the losses, in order to ensure that the insured supplier is motivated to manage its buyers prudently, as the supplier will always share in any losses. So it can be stated that the core value of trade credit insurance is that it provides not only feeling of safety to the supplier, who can be assured that their trade is protected, but also valuable market information on the financial situation of the supplier's customers and, in the case of buyers in foreign countries, on any trading risks peculiar to those countries. As well as by providing an insurance policy that matches the client's patterns of business, trade credit insurers will establish the level of cover that can reasonably be provided to the supplier for trade with each individual buyer by analysing the buyer's financial status, profitability, liquidity, size, sector, payment behaviour and location.

\section{The methodology of evaluation of trade credit insurance as a credit risk management tool}

According to the hypothesis, which is to be verified during the investigation, it was concluded that in order to carry out the assessment of trade credit insurance as a credit risk management instrument, it is necessary to develop a methodology that would not only make this assessment in theoretical aspect but, at the same time, let to establish a link between trade credit insurance usage and Lithuanian business market stability and possibilities of increasing its competitiveness, which in turn can allow to expand the business. Therefore, for developing the methodology, the following trade credit insurance assessment criteria were taken into account:

- credit risk management method;

- relevance of the credit insurance in Lithuanian business market;

- impact of the credit risk on stability of Lithuanian companies;

- impact of the insurance on business development opportunities and increase in competitiveness possibilities.

In order to make an evaluation of practical usage of the trade credit insurance and the relevance in Lithuanian market, the authors has decided to carry out an expert assessment, because there is no statistical data available to perform the analysis. At the same time, the completion of the expert evaluation questionnaire makes it possible to determine the mutual relations between the trade credit insurance, the development potential and the possibilities increasing the competitiveness. However, by analysing Lithuanian business market, first, it is necessary to define the analytical guidelines. As, in this article, the trade credit insurance is considered as a credit management tool, the authors believe that it would be appropriate to assess the market for Lithuanian business enterprises that focus on the trade of goods and services, in the context of business stability and development. Therefore, furtherly in the work the business market will be examined in this particular aspect.

This complex research on trade credit will provide Lithuanian market business representatives with the opportunity to more accurately identify not only the rationality and efficiency of trade credit insurance as a credit risk management tool but also to assess its impact on business development. In addition, the research allows evaluating the efficiency of external trade credit risk management methods without the 
need of large time input, so the developed methodology can be used by Lithuanian companies in order to evaluate the relevance of researched credit risk management tools. It should be noted that the developed methodology can be supplemented by consideration of other alternative trade credit risk management methods.

Qualitative comparative analysis of trade credit insurance and other alternative credit risk management methods

During the analysis of the Lithuanian and foreign scientific literature, it was noticed that relatively little attention is given to determine the suitability of the trade credit risk management. Major part of Lithuanian and foreign scientists usually investigate the trade credit risk management in the context of the legal aspect or the company's financial analysis and do not focus on when and what way to choose in order for efficient and rational use of trade credit risk management. There is also little attention paid to assessing the disadvantages of trade credit risk management methods used in practice by Lithuanian companies. Therefore, the qualitative comparative analysis was chosen for assessment of trade credit insurance as a credit risk assessment tool. Such comparative analysis allows not only to better identify the advantages, disadvantages and benefits of the insurance as the trade credit risk management tool but also to assess its the efficiency and rationality, comparing with other alternatives.

In order to perform this analysis, the following credit risk management's instruments were chosen: trade credit insurance, independent trade credit risk management, integrating services of a credit bureau, factoring, letter of credit, bank guarantee and surety. In order to facilitate the use of the information obtained, qualitative comparative analysis is presented in the table created by authors, with the help of information systematisation (see Table 1).

The analysis and comparison of the above-mentioned trade credit risk management tools led to the conclusion that an independent trade credit risk management integrating services of a credit bureau have rather preventive risk management features, rather than protection features, because all risks and responsibility for losses remain within the company. And although such type of risk management based on the credit bureau services is quite intensively used in Lithuania, according to the authors, this trade credit risk management approach is advantageous only because of its relatively low cost (see Table 1) and only in case of short-term transactions, with small credit limits that cannot cause big damage to the creditors' financial stability and performance if the debtor fails.

Not much of a trade credit risk management features has the surety, as it may be regarded as a reliable guaranty only if there is a sufficient financial capacity of the surety issuer. It should be noted that the validity of a surety lasts only as long as the transaction obligation is valid and ends with the end of the main obligation or with the end of maturity of surety ensuring measures. Also, this risk management method is quite inconvenient at high sales dynamics, as the surety is made each time for each transaction. Especially, it gets inefficient in the context of international trade, as it does not estimate the country risk and, in addition, the guarantor itself may be exposed to this risk. Therefore, author's opinion is that in comparison with other external trade credit risk management tools, the surety as a risk management method has the least number of advantages.

Table 1. Advantages and disadvantages of trade credit risk management tools (Source: author's compilation)

\begin{tabular}{|c|c|c|c|}
\hline \multirow{2}{*}{$\begin{array}{l}\text { Eligibility } \\
\text { assessment } \\
\text { criteria }\end{array}$} & \multicolumn{3}{|c|}{ Trade credit risk management tool } \\
\hline & $\begin{array}{c}\text { Independent trade } \\
\text { credit risk management, } \\
\text { integrating services of a } \\
\text { credit bureau }\end{array}$ & Trade credit insurance & Factoring \\
\hline Advantages & $\begin{array}{l}\text { By collecting and } \\
\text { systematising the entire } \\
\text { information necessary for } \\
\text { trade credit risk } \\
\text { assessment }\end{array}$ & $\begin{array}{l}\text { Cash flows are controlled by the } \\
\text { administration of debts by pre-trial } \\
\text { and legal debt collection or by } \\
\text { paying an insurance claim. Credit } \\
\text { limits and deferred payment terms }\end{array}$ & $\begin{array}{l}\text { Working capital risk } \\
\text { management. The ability } \\
\text { to execute selection of } \\
\text { individual rustomer } \\
\text { transactions r and }\end{array}$ \\
\hline
\end{tabular}




\begin{tabular}{|c|c|c|c|c|}
\hline & $\begin{array}{l}\text { forecasting, the credit } \\
\text { bureau optimises all costs } \\
\text { related to information } \\
\text { collection, classification, } \\
\text { storage and evaluation. } \\
\text { There is no need to invest } \\
\text { in staff and their } \\
\text { competence. Decisions } \\
\text { are made independently. }\end{array}$ & \multicolumn{2}{|c|}{$\begin{array}{l}\text { for new customers are granted on } \\
\text { the basis of the insurer's liability. } \\
\text { The risk of a wrong assessment of } \\
\text { the buyer goes to the insurer. Risk } \\
\text { Diversification. The loss because } \\
\text { of delay in payment, insolvency or } \\
\text { bankruptcy risks is eliminated. }\end{array}$} & accounts. \\
\hline Disadvantages & $\begin{array}{l}\text { In case of payment } \\
\text { delays, insolvency or } \\
\text { bankruptcy, the losses are } \\
\text { not compensated, because } \\
\text { the entire responsibility } \\
\text { for the trade credit limits } \\
\text { and deferred payment } \\
\text { term goes to the creditor. } \\
\text { Debt administration and } \\
\text { collection costs also go to } \\
\text { the creditor. }\end{array}$ & \multicolumn{2}{|c|}{$\begin{array}{l}\text { Does not apply financing of the } \\
\text { trade transactions. Regulates credit } \\
\text { limits and deferred payment terms. } \\
\text { Whole buyer portfolio (sales } \\
\text { turnover) must be covered. The } \\
\text { insurance premium is calculated by } \\
\text { applying a percentage rate to the } \\
\text { insurable turnover. }\end{array}$} & $\begin{array}{l}\text { Only insured transactions } \\
\text { are factorised (or a } \\
\text { recourse right is applied } \\
\text { when all the risks due to } \\
\text { the insolvency of the } \\
\text { debtor go to the creditor). } \\
\text { High financing and } \\
\text { administration fees, a } \\
\text { number of additional } \\
\text { administrative costs. } \\
\text { Financing only in the } \\
\text { range of set credit limits. }\end{array}$ \\
\hline Benefits & $\begin{array}{l}\text { It provides access to the } \\
\text { estimated financial results } \\
\text { and guideline credit } \\
\text { ratings. Provides } \\
\text { information about } \\
\text { payment history, past and } \\
\text { current delays in } \\
\text { payment, garnishment } \\
\text { and bailiffs information. } \\
\text { Offers other additional } \\
\text { useful services. }\end{array}$ & \multicolumn{2}{|c|}{$\begin{array}{l}\text { A competitive advantage is gained. } \\
\text { It provides access to more } \\
\text { favourable conditions of trade } \\
\text { financing. Country and economic } \\
\text { sector risk are managed. No need } \\
\text { for investing in personnel in order } \\
\text { to manage the credit risks. } \\
\text { Convenient at high sales dynamics. } \\
\text { Bad debt record book-keeping } \\
\text { eliminated, thanks to insurance. It } \\
\text { improves the policyholder's } \\
\text { ranking in terms of creditworthy. } \\
\text { Makes the beginning of } \\
\text { cooperation with the little-known } \\
\text { local and export business partners } \\
\text { more secure. }\end{array}$} & $\begin{array}{l}\text { Increased merchant- } \\
\text { ability power. Improves } \\
\text { the competitiveness in } \\
\text { domestic and export } \\
\text { markets. More efficient } \\
\text { customer billing control, } \\
\text { debt administration. } \\
\text { Safer beginning of } \\
\text { cooperation with the } \\
\text { little-known local and } \\
\text { export business partners. }\end{array}$ \\
\hline \multirow{2}{*}{$\begin{array}{c}\text { Eligibility } \\
\text { assessment } \\
\text { criteria }\end{array}$} & \multicolumn{4}{|c|}{ Trade credit risk management tool } \\
\hline & Letter of credit & Bank guarantee & & Surety \\
\hline Advantages & $\begin{array}{l}\text { If the creditor fulfils its } \\
\text { contractual obligations } \\
\text { properly, the payment } \\
\text { settlement is guaranteed. } \\
\text { It allows to calculate in } \\
\text { advance the payment } \\
\text { settlement date and, if } \\
\text { needed, to discount the } \\
\text { letter of credit in order to } \\
\text { obtain the payment for } \\
\text { the deal before a specified } \\
\text { date and to reduce the } \\
\text { working capital } \\
\text { deficiency. }\end{array}$ & $\begin{array}{l}\text { If the debtor breaches the } \\
\text { deal, it ensures that the bank } \\
\text { will fulfil the obligation of } \\
\text { the guarantor's claim, which } \\
\text { meets the guarantee } \\
\text { conditions, without the need } \\
\text { to prove the violation fact. } \\
\text { Unconditionally obliges the } \\
\text { bank to fulfil its obligations. }\end{array}$ & $\begin{array}{l}\text { it en } \\
\text { will } \\
\text { guar } \\
\text { the } s\end{array}$ & $\begin{array}{l}\text { debtor breaches the deal, } \\
\text { ures that the surety issuer } \\
\text { fulfil the obligation of the } \\
\text { intor's claim, which meets } \\
\text { arety conditions. }\end{array}$ \\
\hline
\end{tabular}




\begin{tabular}{|c|c|c|c|}
\hline Disadvantages & $\begin{array}{l}\text { It is established for each } \\
\text { transaction separately and } \\
\text { only at the request of the } \\
\text { debtor. Registration takes } \\
\text { time. High maintenance } \\
\text { costs. Difficult } \\
\text { implementation process. } \\
\text { Full protection occurs } \\
\text { using confirmed and } \\
\text { irrevocable letter of } \\
\text { credit. }\end{array}$ & $\begin{array}{l}\text { Each transaction must have a } \\
\text { separate bank guarantee, so } \\
\text { takes a lot of time to } \\
\text { supervise the entire } \\
\text { customer portfolio. Initiated } \\
\text { only in case of debtor's } \\
\text { agreement. Valid as a safety } \\
\text { measure only if there are } \\
\text { sufficient bank's financial } \\
\text { capacities. }\end{array}$ & $\begin{array}{l}\text { Valid only as the transaction } \\
\text { under the obligation is valid } \\
\text { and ends with the end of the } \\
\text { main obligation or with the end } \\
\text { of maturity of surety ensuring } \\
\text { measures. Protection is valid } \\
\text { only in case of sufficient } \\
\text { financial capacity of the } \\
\text { guarantor. Does not include } \\
\text { assessment of the country and } \\
\text { economic sector risk. }\end{array}$ \\
\hline Benefits & $\begin{array}{l}\text { Confirmed irrevocable } \\
\text { letter of credit eliminates } \\
\text { the risk of incurring } \\
\text { losses in case of debtor's } \\
\text { late payments, insolvency } \\
\text { or bankruptcy. Secures } \\
\text { the beginning of } \\
\text { cooperation with a little } \\
\text { familiar export business } \\
\text { partners. }\end{array}$ & $\begin{array}{l}\text { Eliminating the risk of loss } \\
\text { to the debtor of late } \\
\text { payments, the event of } \\
\text { insolvency or bankruptcy. } \\
\text { Managed country and } \\
\text { economic sector risk. Secure } \\
\text { the beginning of cooperation } \\
\text { with the little-known local } \\
\text { and overseas business } \\
\text { partners. }\end{array}$ & $\begin{array}{l}\text { It allows managing the risk of } \\
\text { non-payment. Reduces the risk } \\
\text { of insolvency of the debtor. }\end{array}$ \\
\hline
\end{tabular}

In summary, it can be stated that in international trade, with a large customer portfolio and sales volume, the trade credit insurance becomes the most effective and rational way to manage credit risk. Additionally, insurance can grant the company with more confidence, which leads to a competitive advantage (the risk of a wrong assessment of the buyer goes to the insurer, and in addition, the risk is diversified and the country and economic sector risks are controlled), because the insurance company guarantees that in case the debtor (buyer) deliberately delays to cover its debts, in event of the insolvency or bankruptcy, the company will regain its sales revenue, because the insurer will help to recover the money by initiating pre-trial or legal debt collection or by paying of the insurance claim. In addition, credit insurance enables possibility of using additional financing of trade transactions through factoring and to control the flow of sales revenue turnover with non-recourse factoring agreement and to obtain more favourable conditions for trade financing from commercial banks. Also, by using trade credit insurance, the company will not need to invest in personnel, their competence (assessment of risks) and risk management tools, and the trade credit risk management process itself with insurance assistance is simple and easy to use. It is important to mention the fact that insurance premiums are not taxed, and the implementation of insurance when managing company's buyer portfolio credit risk allows the policyholder to have higher reliability and creditworthiness ratings.

The examination of expert evaluation of the trade credit insurance as a credit risk management tool

Practical assessment of trade credit insurance efficiency and rationality in Lithuanian market is carried out using the expert evaluation. The aims of expert evaluation are:

to identify the relationship between trade credit insurance and determinants of choosing such as a credit risk management instrument;

to determine the interrelations between trade credit insurance and the potential of development and competitiveness increase;

to find common patterns (if any) reflecting the rationality and efficiency of the researched credit risk management method.

Ten experts participated in the expert evaluation. The following selection criteria were applied for the experts: (1) higher university education; (2) at least 5 years of successful experience in the trade credit risk management; (3) sufficient knowledge of trade credit insurance and not less than 3 years of experience in using this product. 
Based on these criteria, 10 individuals were selected, who can directly make decisions regarding the trade credit risk management or work closely with this product and have deep understanding of it. The experts were communicated in person - by phone and e-mails - so the assessors did not know the composition of the expert group and thus had no impact on each other's opinion (see Table 2):

Table 2. Expert evaluation participants

\begin{tabular}{|l|l|l|l|}
\hline \multicolumn{1}{|c|}{ Expert } & \multicolumn{1}{|c|}{ Position } & \multicolumn{1}{|c|}{ Field of activity } & Experience (years) \\
\hline 1 & Professor & \multicolumn{1}{|c|}{ Insurance } & 23 \\
\hline 2 & Director / Associate professor & Audit / Insurance & 12 \\
\hline 3 & Senior Project manager & $\begin{array}{l}\text { Trade credit insurance / } \\
\text { broker }\end{array}$ & 17 \\
\hline 4 & Chief Financial Officer & Finance / IT & 13 \\
\hline 5 & Country manager & Trade credit insurance 10 & 10 \\
\hline 6 & Chief Financial Officer & $\begin{array}{l}\text { Finance } \\
\text { manufacturing }\end{array}$ & 11 \\
\hline 7 & Chief Executive Officer & IT / Security systems & 16 \\
\hline 8 & Head of risk underwriting department & Insurance/broker & 7 \\
\hline 9 & Head of development & Manufacturing & 12 \\
\hline 10 & $\begin{array}{l}\text { Chief Financial Officer / } \\
\text { Chief Operating Officer }\end{array}$ & Finance / Logistics & \\
\hline
\end{tabular}

The first six questions of the questionnaire identify the expert, his or her professional experience and expertise, so the evaluation will not consider answers to these questions, with accordance to researcher ethics and to guaranteed confidentiality for the experts. In addition, because these questions are not directly related to the assessment, further, they are assessed by a zero value; therefore, the seventh answer that reveals the expert understanding of the trade credit insurance continuously in the research is identified as the first question of the expert evaluation. The first question seeks to identify if the experts correctly understand the subject of credit risk as well to check the expertise of the expert regarding the topic. The analysis of the expert answers to the first question 'Please describe how you understand the trade credit risk' shows that the experts understand and interpret the trade credit risk as one of the operational risks, which could have a substantial impact on business continuity and which is caused by unfulfilment of obligations of one of the transaction parties - the buyer (debtor), like delays in payment or fully / partially failure to pay for the services / goods sold. All the experts agree with the statement that in order to ensure business development, the trade credit risks must be managed.

In order to determine, on what basis the experts evaluate the debtor's credit risk, the third question provided for the experts is 'What must be taken into account in order to assess the debtor's trade credit risk more accurately?' The answers of all 10 experts are provided in Table 3.

Table 3. Debtor's trade credit risk assessment criteria (Source: created by the author on the basis of the expert evaluation)

\begin{tabular}{|l|l|l|l|}
\hline $\begin{array}{l}\text { Debtor's creditworthiness criteria } \\
\text { indicated by the experts }\end{array}$ & $\begin{array}{l}\text { Number } \\
\text { of experts }\end{array}$ & $\begin{array}{l}\text { Debtor's creditworthiness criteria } \\
\text { indicated by the experts }\end{array}$ & $\begin{array}{l}\text { Number of } \\
\text { experts }\end{array}$ \\
\hline The company's financial condition & 10 & Credit bureau recommendations & 2 \\
\hline Debt history & 6 & Legal courts, content of legal procedures & 2 \\
\hline
\end{tabular}




\begin{tabular}{|l|l|l|l|} 
Business sector specifics & 6 & $\begin{array}{l}\text { Collaterals and other negative } \\
\text { information }\end{array}$ & 2 \\
\hline $\begin{array}{l}\text { Buyer's country economic and } \\
\text { political situation }\end{array}$ & 5 & $\begin{array}{l}\text { Information about the shareholders or } \\
\text { founders }\end{array}$ & 2 \\
\hline Credit history & 4 & $\begin{array}{l}\text { Information about the movable and } \\
\text { immovable property }\end{array}$ & 2 \\
\hline Financial performance indexes & 4 & Company size & 2 \\
\hline $\begin{array}{l}\text { The solvency assessment (rating) } \\
\text { Creditworthiness }\end{array}$ & 3 & Company age & 2 \\
\hline $\begin{array}{l}\text { General short-term solvency ratio } \\
\text { Public information about the } \\
\text { company, impartial third-party } \\
\text { reviews }\end{array}$ & 3 & Reserves collected for unforeseen events & 2 \\
\hline Business perspectives & 3 & Countries of export-import partners & 1 \\
\hline & & Business transparency & 1 \\
\hline
\end{tabular}

Results provided in the Table 3 show that the experts evaluate the buyers creditworthiness by a number of criteria and not solely on the basis of company's financial position (company's financial position has been identified by all the experts). Experts consider the debtor's country economic and political risks (identified by five experts), sector risk (identified by six experts), business perspectives (indicated by three experts), debt (indicated by six experts) and credit (indicated by four experts) history, Financial performance indexes (indicated by four experts), legal court history evaluating legal procedures content and ancillary information about the debtors (indicated by three experts) as well as the other information contained in Table 3. On the basis of the set criteria, it is concluded that the experts assess credit risks responsibly, trying to treat it as widely as possible, taking into account the availability of information. This assessment takes a lot of time, as it is based on quantitative and qualitative information that needs lot of time, financial and information resources in order to be collected and assessed.

After examination of the credit risk and the factors determining it, which were considered in terms of creditworthiness criteria, further in the expert evaluation, the trade credit insurance is investigated as a credit risk assessment tool. In order to receive the assessment of the effectiveness of credit insurance from the experts, they were asked to answer the fourth question, which sounds as follows: 'In your opinion, is the trade credit insurance an effective method for credit risk management?' After analysing the answers of all the experts, it was determined that all the participants evaluated the insurance as an effective method. In addition, as the experts had been given an opportunity to provide not only unambiguous answers 'yes / no' but also to express their view in a free form, some experts pointed out that in order to assess the effectiveness of the trade credit insurance as a credit risk management instrument, it must be compared to other alternative credit risk management methods and the pricing of each must be taken into account. Such expert approach to the assessment, on the author's opinion, confirms the competence of the experts and the importance of the comparative analysis carried out by the authors, in order to make the most objective assessment of the trade credit insurance under the research aspect. It should be noted that one of the experts presented an opinion that trade credit insurance efficiency arises not only from the assessment of what the credit risk management area is but also in terms of prices. Therefore, this particular expert indicates that such credit risk management tool requires the user (insurance policyholder) to pay significantly lower cost compared to the bank guarantee (which also has protection features) and other alternative instruments, which have more features of trade financing. Such expert opinion coincides with the author's findings, which are based on a qualitative comparative analysis.

When carrying out the expert evaluation of trade credit insurance as a credit risk management tool, the authors believes that it is appropriate to check and compare the trade credit insurance advantages and 
disadvantages, which were identified by qualitative comparative analysis in theoretical aspect, to the expert's practical opinion. Such comparison will provide more reliability to the obtained data and to the conclusions of the research; therefore, the fifth and sixth expert evaluation questions are meant to determine the advantages and disadvantages of the trade credit insurance as a credit risk management tool on the basis of expert opinion. Systematised expert evaluation results of the above-mentioned questions are presented in Table 4.

Table 4. The advantages and disadvantages of the trade credit insurance as a credit risk management tool based on expert evaluation (Source: created by the authors based on the expert evaluation)

\begin{tabular}{|c|c|}
\hline $\begin{array}{c}\text { Eligibility } \\
\text { assessment } \\
\text { criteria }\end{array}$ & Trade credit insurance \\
\hline Advantages & $\begin{array}{l}\text { Effective administrative cost optimisation: debt collection and debtor credit assessment is } \\
\text { passed to the insurer; therefore, staff workload is reduced. Elimination of bad debts: } \\
\text { protects the company's balance sheet from the bad / non-payable debts. Risk management: } \\
\text { the risks are diversified, the risk of a wrong assessment of the buyer is passed to the } \\
\text { insurer, provides reliable assessment of the creditworthiness of debtors, risk supervision } \\
\text { (customer credit risk monitoring; in-depth creditworthiness assessment, when searching } \\
\text { for links to other activities of the company owners and shareholders). Cash flow control } \\
\text { and optimisation: by reducing the incidence of overdue accounts, quantities and volumes; } \\
\text { debtors become more disciplined, losses owing to the debtor's insolvency or bankruptcy } \\
\text { risks are eliminated. A competitive advantage is achieved. Country and economic sector } \\
\text { risks are managed. Let's the company to put stronger focus on its core business, } \\
\text { respectively increasing its operational efficiency. Standardisation of internal processes. } \\
\text { Professional and comprehensive insurer's support. Good measure for contributing to the } \\
\text { development of the company in terms of overall stability. Improves the policyholder } \\
\text { creditworthiness rating, increases company's confidence and establishes a credible image } \\
\text { of the company, raises the prestige of the company. Secures the beginning of cooperation } \\
\text { with a little familiar business partners. }\end{array}$ \\
\hline Disadvantages & $\begin{array}{l}\text { A complicated formulation of insurance agreement (policy). Improper for covering risks } \\
\text { of atypical trade deals. Long waiting period insurance claim payment. In some cases, } \\
\text { expensive (at a smaller customer portfolio / sales turnover). In order that the trade credit } \\
\text { insurance to be operated correctly, an active policyholder's actions and the adaptation of } \\
\text { internal processes to the insurance conditions is required. In case of inability to apply } \\
\text { these actions and to implement a risk management framework, the trade credit insurance } \\
\text { may be unsuited to the company's activities and possibly will not bring the expected } \\
\text { benefits. Often, the credit limits granted by the insurers are less than that preferred by } \\
\text { creditor, thus limiting sales. Long-term decision-making. Strict rules and procedures (e.g. } \\
\text { insurance claim indemnification). Quite difficult to implement, monitor and manage the } \\
\text { granted credit amounts when the number of buyers is sufficient enough (e.g. } 350 \text { and } \\
\text { more), where invoice are issued very often and in relatively small amounts. Newly } \\
\text { established and little companies (buyers) are treated very strictly, thus restricting the trade } \\
\text { with them. Buyers from insurance-prohibited countries are not covered. }\end{array}$ \\
\hline
\end{tabular}

After the examination of advantages and disadvantages of the trade credit insurance as a credit risk management tool identified by the experts, the insurance rationality assessment is being carried out. When experts were asked, under what conditions insurance may be considered as rational credit risk management instrument and under what conditions such management method is ineffective, the following data was obtained and is provided in Table 5. 
Table 5. Factors (conditions) determining the rationality and inefficiency of trade credit insurance as a credit risk management tool (Source: created by the authors on the basis of expert evaluation)

\begin{tabular}{|c|c|}
\hline Rational method & Ineffective method \\
\hline $\begin{array}{l}\text { In case of growing exports and a stable } \\
\text { macroeconomic environment of the country; }\end{array}$ & $\begin{array}{l}\text { In case of trading / providing services to companies } \\
\text { operating in non-insurable countries or with increased } \\
\text { credit risk; }\end{array}$ \\
\hline $\begin{array}{l}\text { Under well-established buyer portfolio flow } \\
\text { and similar credit terms of receivables } \\
\text { obligations; }\end{array}$ & $\begin{array}{l}\text { In case of trading / providing services to newly } \\
\text { established firms / public institutions / individuals; }\end{array}$ \\
\hline $\begin{array}{l}\text { When trading in domestic and foreign markets, } \\
\text { applying deferred payment terms; }\end{array}$ & If buyers are paying in advance for goods or services; \\
\hline $\begin{array}{l}\text { When company is in process of expanding its } \\
\text { business; }\end{array}$ & $\begin{array}{l}\text { Having a smaller buyer portfolio or working in the local } \\
\text { market with well-known clients; }\end{array}$ \\
\hline $\begin{array}{l}\text { In case of non-payment risk increase in the } \\
\text { market and uncertain economic situation; }\end{array}$ & $\begin{array}{l}\text { When a separate buyer cannot affect the company's } \\
\text { financial stability, and the company has and uses } \\
\text { resources / tools to manage these risks; }\end{array}$ \\
\hline $\begin{array}{l}\text { In order to effectively regulate the overdue } \\
\text { trade account receivables; }\end{array}$ & $\begin{array}{l}\text { Working in high-risk conditions - regardless of objective } \\
\text { recommendations about the creditworthiness of the buyer } \\
\text { provided by the insurer. }\end{array}$ \\
\hline \multicolumn{2}{|l|}{$\begin{array}{l}\text { Having a large portfolio of account receivables } \\
\text { (harder to assess each individual buyer), } \\
\text { especially when working in foreign markets; }\end{array}$} \\
\hline $\begin{array}{l}\text { When each individual buyer can influence the } \\
\text { company's financial stability and the company } \\
\text { does not have or does not use the resources / } \\
\text { tools to manage these risks. }\end{array}$ & \\
\hline
\end{tabular}

Based on the data presented, it can be stated that the expert's opinion regarding factors determining the trade credit rationality and inefficiency have separated. Most of the experts argued that trade credit insurance is a rational credit risk management tool as for domestic and foreign markets when the credit terms are applied. However, there was also an expert claiming that when trading / providing services only in the local market, the trade credit insurance is not an effective method for credit risk management, reasoning it with clients' 'notoriety'. Also, expert opinions are separated regarding the method's rationality in terms of the flow dynamics of buyer portfolios. Although the majority of experts assign trade credit insurance to the rational risk management instrument in case of a small buyer portfolio, where each individual buyer can influence the company's financial stability, one of the experts attributed the same condition to the factors determining the inefficiency of this risk management tool.

In order to determine the relationship between trade credit insurance and the company's development prospects through the aspect of sales and competitiveness increase and cash (income) flows, the experts were asked to evaluate the benefits of the method for each of the criteria by evaluating it from 0 to 10 points, where 0 is valued as the absence of benefit (impact), 1 point as little benefit and 10 points as big benefit (impact).

The results gathered during the expert evaluation are provided in Figure 2. Benefit of credit risk insurance is evaluated in terms of aim: criteria 1 - to manage company's account receivables; criteria 2 - to manage company's working capital; criteria 3 - to increase sales revenue; criteria 4 - to increase company's competitiveness; criteria 5 - to increase company's goodwill. 


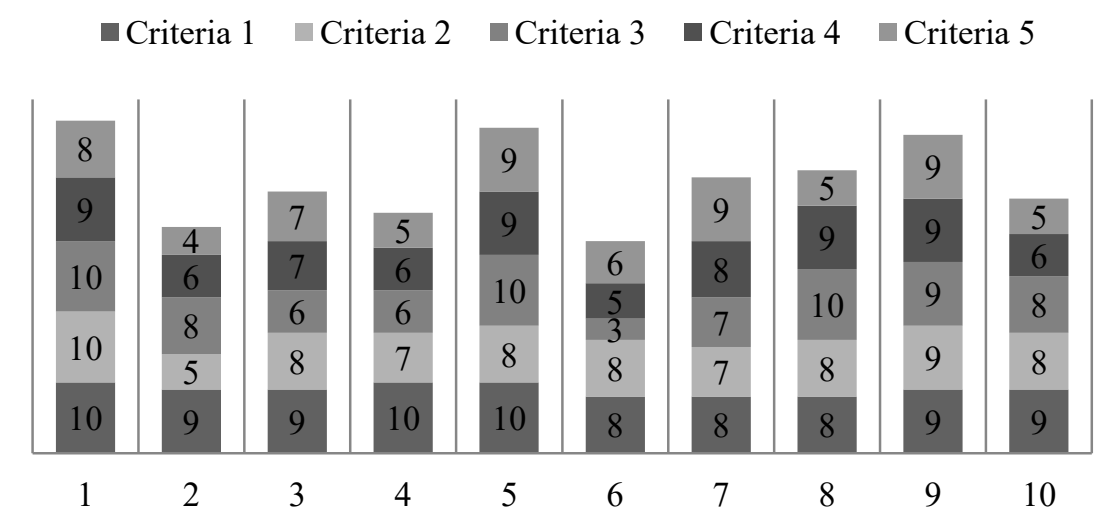

Figure 2. Credit insurance benefits, which are provided for companies to increase sales and competitiveness and to manage income flows (Source: created by the authors based on the expert evaluation)

The data provided in the graph shows that depending on the expert, the influence of the researched credit management instrument under the criteria provided is evaluated differently. The first, fifth and ninth experts in accordance with all criteria have assessed the benefits of the trade credit insurance as a significant or very significant, assigning the evaluations from 8 to 10 points. It should be noted that according to the first criterion (in order to manage company's account receivables), the insurance benefits were rated as very important by all the experts. Also, the trade credit insurance was estimated by the second criteria (in order to manage company's working capital) as a fairly big benefit of the credit risk management tool. Only one expert indicated such method as little effective in regards to this aspect. The expert opinions were highly separated regarding the benefits provided by the trade credit insurance under the third criterion - in order to increase sales revenue. The vast majority $(70 \%)$ of the experts estimated the impact of the insurance in this aspect as a very significant or significant (from 7 to 10 points), but 20\% attributed the benefits to the less significant (5-6 points) and the sixth expert superficially evaluated the benefits provided by the trade credit insurance as little significant under the researched criteria. Also, the experts' opinion was divided regarding the benefits provided by the fourth and fifth criteria as follows:

$60 \%$ of the experts attributed the insurance to a method that provides a big benefit when seeking for company's competitive advantage, but $40 \%$ of the experts estimated the impact of the insurance to competitive advantage as less significant, assigning assessments from 5 to 6 points;

$50 \%$ of the experts estimated the insurance as a method that provides many benefits for increasing the prestige of the company and, on the other hand, the same number of experts assessed its impact on the increase in company's prestige as less significant or very little significant (4-6 points).

Summarising the results of the expert evaluation, further, the total assessment of benefits provided by the insurance for increasing company's sales revenues and competitiveness and for cash flow management, by the influence of each criterion is presented in Figure 3.
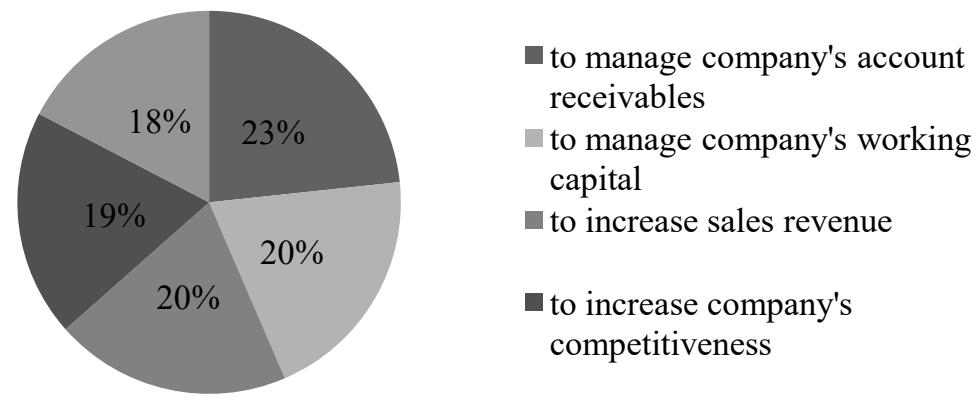

Figure 3. Impact of credit insurance on increasing company's sales and competitiveness and on income flow management (Source: created by the authors on the basis of expert evaluation) 
The last four expert evaluation questions are asked by the authors in order to determine the relationship between the use of trade credit insurance and Lithuanian business market stability and opportunities of competitiveness increase as well as to identify the impact of trade credit insurance on Lithuanian business market at a macrolevel (if such impact exists). Considering the competence of the participants of the expert evaluation, experts are invited to assess the influence of the trade credit insurance in order to increase the competitiveness of the Lithuanian business sector in foreign markets and its impact (if any) on Lithuanian export-import balance indicators and gross domestic product (GDP) (when Lithuanian companies are using insurance as a credit risk management tool). Also, the authors decided to check the assumption provided in the work that trade credit insurance is an efficient and rational method for credit risk management in the context of Lithuanian business market, on the basis of experts competence and to verify the hypothesis that the trade credit insurance in Lithuanian business market is an efficient and rational way of credit risk management in order to develop the business. The received data is presented in Table 6 .

Considering the data presented in Table 6 , it can be stated that although trade credit insurance influence for the nominated goals is assessed differently by the experts, the relations themselves between trade credit insurance and competitiveness increase in foreign markets, as well the Lithuanian export-import balance indicators and GDP - were unambiguously identified by all the experts.

Table 6. Determination of the relations between the appliance of trade credit insurance (TCI) and Lithuanian business market stability and the evaluation of competitiveness increase opportunities (Source: created by the author based on the expert evaluation)

\begin{tabular}{|c|c|c|c|c|c|c|c|c|c|c|c|c|c|c|}
\hline $\mathbf{Q}$ & Criteria & Criteria & Grade & & pe & & & & & & & & & Average \\
\hline & & & & 1 & 2 & 3 & 4 & 5 & 6 & 7 & 8 & 9 & 10 & \\
\hline 10 & 6 & $\begin{array}{l}\text { The influence of the implementation in } \\
\text { order to increase the competitiveness of } \\
\text { Lithuanian business sector in foreign } \\
\text { markets }\end{array}$ & $\begin{array}{l}\text { From } \\
0 \\
\text { to } 10\end{array}$ & 9 & 9 & 9 & 9 & 9 & 5 & 8 & 7 & 9 & 7 & 8.1 \\
\hline 11 & 7 & $\begin{array}{l}\text { The impact of the TCI implementation in } \\
\text { Lithuanian companies has or may have on } \\
\text { Lithuanian export-import balance } \\
\text { indicators and GDP }\end{array}$ & $\begin{array}{l}\text { From } \\
0 \\
\text { to } 10\end{array}$ & 8 & 3 & 8 & 8 & 8 & 8 & 8 & 4 & 9 & 7 & 7.1 \\
\hline 12 & 8 & $\begin{array}{l}\text { The TCI is an efficient and rational } \\
\text { method for credit risk management in } \\
\text { context of Lithuanian business market }\end{array}$ & $\begin{array}{l}\text { Yes: } 1 \\
\text { No: } 0\end{array}$ & 1 & 1 & 1 & 1 & 1 & 1 & 1 & 1 & 1 & 1 & 1 \\
\hline 13 & 9 & $\begin{array}{l}\text { The TCI in Lithuanian business market is } \\
\text { efficient and rational way of credit risk } \\
\text { management in order to develop the } \\
\text { business }\end{array}$ & $\begin{array}{l}\text { Yes: } 1 \\
\text { No: } 0\end{array}$ & 1 & 0 & 1 & 1 & 1 & 1 & 1 & 1 & 1 & 1 & 0.9 \\
\hline
\end{tabular}

It should be noted that although expert opinion on the significance of influence have separated, however, the vast majority of experts $(90 \%)$ identified it as a very significant or significant enough in order to increase competitiveness in foreign markets and by assessing the insurance impact on Lithuanian export-import balance indicators and GDP.

Summarising the carried-out expert evaluation, it is concluded that the trade credit insurance is seen as an efficient and rational method for credit risk management by the experts in context of Lithuanian business market in order to develop the business. Its benefits and impact on the company aims to manage the company's account receivables are assigned to a very significant category - the average of significance is 9 (maximum score is 10 points), whilst the impact on the objectives to manage the company's working capital and to increase sales revenue and company's competitiveness and goodwill is estimated as significant (significance average ranging from 6.7 to 7.8). By considering the 
advantages and disadvantages of the trade credit insurance identified by the experts, it is decided that often the purpose of the trade credit insurance itself is identified as disadvantage - to protect the policyholder against credit risk on the basis of a very broad and deep credit rating evaluation methodology, which provides credit limit granting. Some experts evaluate credit limit granting procedure as a restriction in trading process; however, in fact, the purpose of such limits is to reduce the credit risk to an acceptable and reasonable one. Yet, some new gaps that have not been detected during the qualitative comparative analysis were identified - long insurance claim payment waiting and decision-making period and the need to adapt the internal processes to the insurance conditions without implementing a risk management framework and without correct estimation of insurance claims payment terms, the trade credit insurance cannot provide the expected benefits. Analysing rationality and inefficiency of the insurance, it is concluded that the inefficiency is often treated by the experts not on the basis of certain insurance function efficiency, but according to its using suitability, which leads to an incorrect final evaluation. Also, during the carried out assessment, a link between trade credit insurance and the company's development prospects expressed through the insurance company's impact on sales and competitiveness increase and income flow management has been identified.

\section{Conclusions}

After carrying out the analysis of the trade credit insurance as a credit risk management tool in the context of the disadvantages, advantages and benefits and after investigating its effectiveness, efficiency and inefficiency based on theoretical (qualitative comparative analysis) and practical (expert evaluation) aspects, the authors consider that it would be appropriate to carry out a summarised insurance assessment that combines and examines the obtained results.

Assessing the debtor's crediting opportunities, it is necessary to assess its solvency, liquidity, operational efficiency and profitability indicators, to analyse company's level of liability and capital structure, evaluate the possibility of bankruptcy and take into account the debtor's disposable amount of money. During the examination of internal non-financial factors, it is advisable to rely on the company's strategy and business policy, to investigate the behaviour of the staff and management, to pay attention to the company's participation in legal proceedings and to assess the company's legal liability. External factors are particularly important when assessing the creditworthiness of foreign customers because under international trade conditions, solvency risks depend not only on the internal, financial and non-financial situations but also on the buyer's country's political, economic and other risks and cultural peculiarities. Unfortunately, the assessment of debtors' ability to pay often confronted with the problem of data reliability and accessibility. In addition, information collection and evaluation requires a lot of expertise, time and money, what makes profitable transactions at first sight, less useful and sometimes even unprofitable. Especially, the trade credit risk assessment problems are reflected in international trade, as some foreign countries' laws and legal systems hinder the availability of information and its collection to a level that it becomes simply impossible to perform.

The carried-out assessment of scientific literature concluded that in order to perform the assessment of trade credit insurance as a credit risk management tool, it is necessary to develop a methodology that could allow to evaluate the effectiveness of trade credit insurance not only in the theoretical aspects but also to define the relationship between application of trade credit insurance and the possibilities of increasing the stability and competitiveness of Lithuanian business market on the practical side. For this reason, the authors have proposed a methodology that combines theoretical and practical research methods. First of all, with the assistance of qualitative analysis, the alternative external credit risk management tools were examined. Such analysis allows not only to identify the advantages, disadvantages and benefits of researched risk management tools but also to assess the efficiency and rationality of trade credit insurance in the context of alternative methods. In order to carry out an assessment in the practical aspect, considering the lack of statistical data, it was decided additionally to perform an expert evaluation. At the same time, by completing the expert evaluation questionnaire, it becomes possible to determine the links between the trade credit insurance, the development potential and competitiveness increase on the basis of business sector insights. The assessment, which 
is made in accordance with the methodology, combining qualitative analysis and expert evaluation is more solid, because the assessment of the trade credit insurance in the theoretical aspect additionally includes experts who are decision-maker in their field and who are well aware of the researched product from the practical side.

In the authors' opinion, only insurance and bank guarantee have genuine trade credit risk management features. Both management tools ensure that in case if the events provided in the contract (insurance policy) or a guarantee (bank) occur, the creditor will receive the payment, so the creditor will not suffer losses because of the debtor's insolvency, delayed payment or bankruptcy. Nevertheless, comparing insurance and bank guarantee, the authors believe that insurance is more effective and rational trade credit risk management method, which additionally gives the creditor a lot of advantages. In addition, credit insurance enables possibility of using additional financing of trade transactions through factoring and to control the flow of sales revenue turnover with non-recourse factoring agreement and to obtain more favourable conditions for trade financing from commercial banks. Also, by using trade credit insurance, the company will not need to invest in personnel, their competence (assessment of risks) and risk management tools. Furthermore, the implementation of insurance when managing company's buyer portfolio credit risk allows the policyholder to have higher reliability and creditworthiness ratings. Although in terms of the price, insurance may be more expensive instrument than a bank guarantee (according to applicable premium rates).

After performing an assessment of trade credit insurance, it was concluded that in international trade, with a large buyer portfolio and high sales volume, the trade credit insurance becomes the most effective and rational way to manage credit risk, which eliminates the losses because of the debtor's insolvency or bankruptcy, manages countries and sector's risks and helps to discipline the debtor, what determines the decline in overdue accounts frequencies, amounts and volumes. In addition, credit insurance provides possibility to finance trading transactions and to control the working capital flow by using additional factoring service and to obtain more favourable conditions for trade financing from commercial banks. It is important to mention the fact that the implementation of insurance by the company in order to manage credit risk provides the policyholder with a higher reliability and credit rating. Furthermore, it is an effective method to optimise the administrative costs. Also, it is simple and convenient to use management tool. All of this allows businesses representatives to focus more on the core business by increasing its operational efficiency, gaining a competitive advantage and the opportunity to expand their business.

\section{References}

Ferrando A., Mulier K. (2012). Do Firms Use the Trade Credit Channel to Manage Growth? European Central Bank (ECB) working paper No. 1502. [Accessed 15.09.2016]. Available from Internet:

https://www.ecb.europa.eu/pub/pdf/scpwps/ecbwp1502.pdf7b3f759c3bda2048d23f62bad122d1 86d

Jasiene M., Laurinavicius A. (2009). Kredito rizikos valdymo jmonese problemos ir jij sprendimo budai. Verslas: teorija ir praktika. (10), 15-29.

Jones P. M. (2010). Trade Credit Insurance. The World Bank primer series on insurance (15). [Accessed 18.09.2016]. Available from Internet: http://siteresources.worldbank.org/FINANCIALSECTOR/Resources/ Primer15 TradeCreditInsurance Final.pdf

Li Y. et al. (2014). Trade credit insurance, capital constraint, and the behavior of manufacturers and banks. Springer Science and Business Media (240), 20.

Nilsen J.H. (2002). Trade Credit and the Bank Lending Channel. Journal of Money, Credit and Banking, (34), 226-253.

Paul S. Y. (2007).Trade Credit: Understanding Its Importance. Journal of the Chartered Institute of Credit Management (3), 42-45.

Paul S.Y., Boden R. (2012). Getting Paid: Lessons for and from SMES. Association of Chartered Certified Accountants. [Accessed 07.09.2016]. Available from Internet: http://www.accaglobal.com/content/dam/acca/global/PDF-technical/small-business/pol-tp-gp.pdf 
Pike R., Cheng N. S. (2001). Credit Management: An Examination of Policy Choice, Practices and Late Payment in UK Companies. Journal of Business Finance \& Accounting (27), 1013-1042. [Accessed 11.10.2016]. Available from Internet: http://onlinelibrary.wiley.com/doi/10.1111/1468-5957.00403/abstract

Pridotkiene J. (2011). Prekinio kredito rizikos veiksniu vertinimas: rytu ir vakaru rinku rizikingumas eksportuotojo požiūriu. Ekonomika ir vadyba (16), 273-279.

Pridotkiene J., Snieskiene G. (2011). Prekinio kredito rizikos formavimosi prielaidos eksporto atveju. Ekonomika ir vadyba (16), 280-286.

Rutkauskas A. V. (2008) On the sustainability of regional competitiveness development considering risk. Technological and Economic Development of Economy: Baltic Journal on Sustainability (14), 88-99.

The International Credit Insurance \& Surety Association (ICISA) publicly available information. [Accessed 11.11.2016]. Available from Internet: http://www.icisa.org/publications/1583/mercury.asp?page id=1941,

Trade credit insurance company Atradius, publicly available information about trade credit risk evaluation and insurance services. [Accessed 07.09.2016]. Available from Internet: http://global.atradius.com/products/creditinsurance/credit-insurance.html

Trade credit insurance company COFACE, publicly available information about trade credit risk evaluation and insurance services. [Accessed 07.09.2016]. Available from Internet: http://www.coface.lt/Mes-siulome/Valdytisavo-rizikas

Trade credit insurance company Euler Hermes, publicly available information about trade credit risk evaluation and insurance services. [Accessed 07.09.2016]. Available from Internet: http://www.eulerhermes.com/ products-solutions/ credit-insurance/Pages/default.aspx 